\title{
Essential Oils as Natural Fungicides to Control Rhizopus stolonifer-Induced Spoiled of Strawberries
} \author{
Henriette Monteiro Cordeiro de Azeredo ${ }^{4,5}$ (i), Marcos David Ferreira 5 (D)

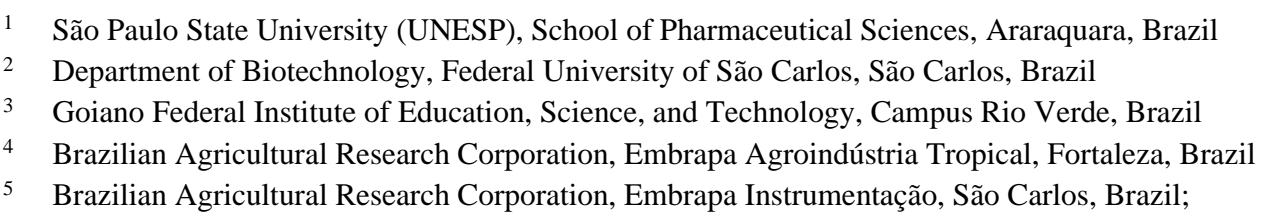

Josemar Gonçalves Oliveira Filho 1,*(D), Guilherme da Cruz Silva ${ }^{2}$ (D), Mariana Buranelo Egea ${ }^{3(D)}$,

Received: 6.01.2021; Revised: 27.01.2021; Accepted: 31.01.2021; Published: 8.02.2021

\begin{abstract}
Strawberry is a highly desirable fruit with a unique taste and a good source of bioactive compounds beneficial to human health. However, it has a short post-harvest shelf life, mainly due to the soft rot caused by Rhizopus stolonifer. This study aimed to evaluate the antimicrobial properties of essential oils (EOs) of Mentha piperita, Cymbopogon martinii, Cinnamomum camphora, and Mentha spicata using spore germination and micro-well dilution assays, and to test the effects of the vaporphase application of $M$. spicata and $C$. martini on the incidence and severity of soft rot in strawberry artificially inoculated with $R$. stolonifer. In in vitro tests, $C$. martinii and M. spicata EOs were the most effective, inhibiting more than $95 \%$ of the spore germination. Additionally, in the microwell dilution test, these EOs had the lowest minimum inhibitory concentration (MIC) and minimum fungicidal concentration (MFC) (5 and $10 \mu \mathrm{g} / \mathrm{mL}$, respectively), and for the microwell dilution test, the lowest MIC $(5 \mu \mathrm{g} / \mathrm{mL}$ and $10 \mu \mathrm{g} / \mathrm{mL}$, respectively) and MFC (10 $\mu \mathrm{g} / \mathrm{mL}$ for both). High in vivo inhibitory effects of M. spicata and C. martinii EOs were observed at $10 \%$ concentration, with 100 and $78 \%$ reduction, respectively, in the $R$. stolonifer-induced spoilage. Our results suggest that $C$. martinii and M. spicata EOs can be used as efficient natural fungicides and can be an alternative to synthetic fungicides for preserving fresh strawberries from soft rot.
\end{abstract}

Keywords: plant essential oils; minimal inhibitory concentration; natural antifungal agent; soft rot.

(C) 2021 by the authors. This article is an open-access article distributed under the terms and conditions of the Creative Commons Attribution (CC BY) license (https://creativecommons.org/licenses/by/4.0/).

\section{Introduction}

Strawberry (Fragaria $\times$ ananassa) is a fruit cultivated and appreciated worldwide, mainly for direct consumption and processing value-added products [1]. It is rich in beneficial bioactive compounds, such as vitamins, $\beta$-carotene, and phenolic compounds [2]. However, because of their high respiration rate and soft texture, ripe fruits have a short post-harvest life, mainly due to infection of phytopathogenic fungi, which changes their physical-chemical characteristics and reduces shelf life [3].

Rhizopus stolonifer is one of strawberry's main storage pathogens that contributes to the ripe fruits' high spoilage during post-harvest life. It causes soft rot that, under high humidity conditions, covers the fruit with mycelium, interspersed with pathogens' structures [4]. Although this infection can be controlled efficiently using synthetic fungicides, these additives can be harmful to human and plant health. In addition, fungicides can form long-term residues 
in the environment and promote resistance to their active principles in the fungal populations $[5,6]$. A better alternative to synthetic fungicides must reduce these indirect economic costs $[6]$.

Among the new natural alternatives, essential oils (EOs) show great potential for controlling phytopathogenic fungi because of their high antifungal activity, low toxicity, and low environmental impact [7]. EOs are secondary metabolites produced by plants in response to adverse conditions. They have high volatility, intense aroma, and good solubility in organic solvents [8]. In vitro studies have indicated their high antimicrobial activity in direct contact tests (liquid phase); however, relatively higher concentrations are necessary to see these effects in vivo. At high concentrations, their strong aroma can modify the flavor of the food [9]. To minimize the sensory impact of EOs and make their application feasible for the products that are sensitive to immersion treatments, the use of EOs in the volatile vapor phase is an option. This can reduce the amount needed to guarantee the optimum antimicrobial effect and the least impact on the target food's sensory properties [10]. Applying EOs using the vapor phase is an interesting, new alternative that allows its useful bioactivity as an antimicrobial agent to preserve perishable food products [10-12]. El Ouadi et al. [13] demonstrated that the EO of Melissa officinalis in the vapor phase could control Botrytis cinerea, Penicillium expansum, and Rhizopus stolonifer in apples. Thus, this study aimed to evaluate the antimicrobial activity of Cymbopogon martinii, Cinnamomum camphora, Mentha spicata, and Mentha piperita OEs using spore germination and micro-well dilution methods as well as the incidence and severity of soft rot in strawberry artificially inoculated with $R$. stolonifer after vapor-phase application of M. spicata and C. martini.

\section{Materials and Methods}

\subsection{Materials.}

Essential oils of pippermint (Mentha piperita) lot 1123, palmarosa (Cymbopogon martinii) lot 2489, and ho wood (Cinnamomum camphora) lot 1369 were purchased from Laszlo Aromaterapia (Belo Horizonte, Minas Gerais, Brazil), and mint (Mentha spicata) lot 197 EO was purchased from Ferquima Ind. e Com. Ltda. (Vargem Grande Paulista, São Paulo, Brazil). All EOs used in this study were extracted by hydrodistillation, as per the companies' information on the product labels. The fungal strain $R$. stolonifer CCT 0276 was obtained from Andre Tosello Foundation (Campinas, São Paulo, Brazil). The chemical profiles of EOs were determined using gas chromatography and mass spectrometry (GC-MS, QP-5000, Shimadzu, Columbia, MD, USA) previously and published by our research group [14]. The major volatile contents (i.e., $\geq 1 \%$ ) of $M$. piperita EO were menthol $(45.37 \%)$, menthone $(20.13 \%)$, isomenthone $(16.94 \%)$, menthyl acetate $(3.81 \%)$, pulegone $(1.89 \%)$, $\alpha$-terpinene $(1.88 \%)$, isopulegol (1.83\%), neoisomenthol (1.19\%), and $\alpha$-terpineol $(1.08 \%)$, while that of $C$. camphora EO was oxygenated monoterpene linalool (98.39\%). The EO of C. martinii had geraniol $(83.82 \%)$, geranyl acetate $(7.49 \%)$, linalool $(2.48 \%)$, and caryophyllene $(1.33 \%)$ as the major volatile compounds, whereas that of $M$. spicata showed carvone $(61.71 \%)$, limonene (20.22\%), 1,8-cineole (5\%), sabinene $(2.28 \%)$, cis-dihydrocarvone (1.63\%), and $\alpha$-thujene $(1.4 \%)$ as the major volatile compounds. 
2.2. Determination of the in vitro antifungal activity of essential oils.

\subsubsection{Spore germination assay.}

Germination tests were conducted as described by Pimentel et al. [15], with some modifications. Briefly, $100 \mu \mathrm{L}$ of $R$. stolonifer or $B$. cinerea conidia suspension $\left(2 \times 10^{5}\right.$ conidia per $\left.\mathrm{mL}\right)$ was mixed with $100 \mu \mathrm{L}$ of each EO. Tween $80(0.05 \% \mathrm{v} / \mathrm{v})$ was used as a negative control. Microscope cavity slides containing the mixtures were incubated at $25^{\circ} \mathrm{C}$ for $24 \mathrm{~h}$ in a Petri dish with wet filter paper, and the germination was observed under an Optical Systems Nova 107 light microscope. A total of 200 spores were counted, and the percentage of germinated conidia was calculated using the number of conidia germinated/total number of conidia.

\subsubsection{Micro-well dilution method.}

Fungal growth inhibition was tested as described by Broekaert et al. [16]. Briefly, a mixture of $10 \mu \mathrm{L}$ of conidial suspension and $90 \mu \mathrm{L}$ of yeast potato dextrose broth were incubated in a 96 -well microtiter plate for $16 \mathrm{~h}$ at $26 \pm 2{ }^{\circ} \mathrm{C}$. An aliquot $(100 \mu \mathrm{L})$ of each 2 -folddiluted sample was added to a $96-$ well plate at $0.156-20 \mu \mathrm{g} / \mathrm{mL}$ and incubated again at $26 \pm 2{ }^{\circ} \mathrm{C}$. Tween $80(0.05 \% \mathrm{v} / \mathrm{v})$ served as a negative control. After incubation, $10 \mu \mathrm{L}$ of cell viability indicator (2,3-5-triphenyl tetrazolium chloride 1\%) was added to each well and incubated at $37^{\circ} \mathrm{C}$ for $1 \mathrm{~h}$. Minimum inhibitory concentration (MIC) was defined as the lowest concentration of essential oil that shows no color change, while minimal fungicidal concentration (MFC) was defined as the lowest concentration that completely inhibits subculture growth; for this, $5 \mu \mathrm{L}$ of cultures were subcultured subsequently on PDA plates at $26 \pm 1^{\circ} \mathrm{C}$ for 5 days.

\subsection{In vivo tests: determination of the antifungal activity of essential oil vapors against $R$.} stolonifer on strawberries.

For this, the EOs of M. spicata and C. martini, which were more effective in the in vitro experiments, were emulsified at $2.5 \%, 5 \%$, and $10 \%(\mathrm{v} / \mathrm{v})$ concentrations distilled water using Tween $80(0.05 \% \mathrm{v} / \mathrm{v})$ as a surfactant. Emulsions were prepared by mixing the EO and the aqueous phase in a high-speed mixer (UltraTurrax T25, IKA Werke GmbH \& Co, Staufen, Alemanha) for $5 \mathrm{~min}$ at 5,000 rpm.

Strawberries (Fragaria x ananassa) were purchased from a local market (São Carlos, $\mathrm{SP}$, Brazil). The specimens were selected based on their appearance and freshness and then sanitized using $2.5 \%$ sodium hypochlorite. Batches of 3 fruits were inoculated with $R$. stolonifer spores using $30 \mu \mathrm{L}$ of a spore suspension $\left(10^{5}\right.$ spores $\left.\mathrm{mL}^{-1}\right)$ in $3 \mathrm{~mm}$ deep wounds and were placed in transparent plastic containers $(157 \times 130 \times 40 \mathrm{~mm}$, Galvanotec, GA 92, Carlos Barbosa, Rio Grande do Sul, Brazil). These were treated with $1 \mathrm{~mL}$ of each EO emulsion soaked in cotton balls attached to the containers' edge and sealed with Parafilm ${ }^{\circledR}$ to prevent vapors' leakage. The fruits were stored at $25 \pm 2^{\circ} \mathrm{C} /$ at $80 \pm 5 \%$ relative humidity for 7 days, with a photoperiod of $12 \mathrm{~h}$. The treatments' efficacy was evaluated based on the incidence and severity of the infection in the fruits. Seven days after the inoculation, disease incidence was calculated from the number of symptomatic fruits in relation to the total number of fruits used for each treatment. The results were expressed as a percentage (\%) [17]. Severity of infection was calculated on a scale of $6(0=$ no symptoms; $1=$ infection in $1 \%-20 \%$ of the wounded 
area; $2=$ in $21 \%-40 \%$ area; $3=$ in $41 \%-60 \%$ area; $4=$ in $61 \%-80 \%$ area and $5=$ infection in more than $81 \%$ of the wounded area) [18].

\subsection{Statistical analysis.}

The standard deviation of the means was calculated, and the statistical difference of the means at a $5 \%$ significance level $(\mathrm{p}<0.05)$ was determined by the Tukey test. In the in vivo tests, the experimental design was randomized in a factorial scheme $(7 \times 3)$, with seven treatments and three concentrations (Control; 2.5\%, 5\%, and 10\% EO of M. spicata; $2.5 \%, 5 \%$, and $10 \% \mathrm{EO}$ of $C$. martinii). The relative frequency was calculated, and the statistical difference at $5 \%$ significance level $(\mathrm{p}<0.05)$ was calculated using the Kruskal-Wallis test.

\section{Results and Discussion}

\subsection{Spore germination assay.}

Essential oils of M. spicata and C. martinii showed respectively $95.5 \%$ and $98.6 \%$ inhibition of germination of $R$. stolonifer spores, the highest among the EOs tested, while that of $C$. camphora had the lowest inhibition (69.3\%) (Figure 1). Under the experimental conditions, control (0.5\% Tween 80$)$ was completely unable to inhibit spore germination, presenting a $100 \%$ score. Present results match those reported previously [19-21]. Although the capacity of EOs to inhibit spore germination is reported in the literature, the possible mechanisms of action of these oils and their major constituents are not known.

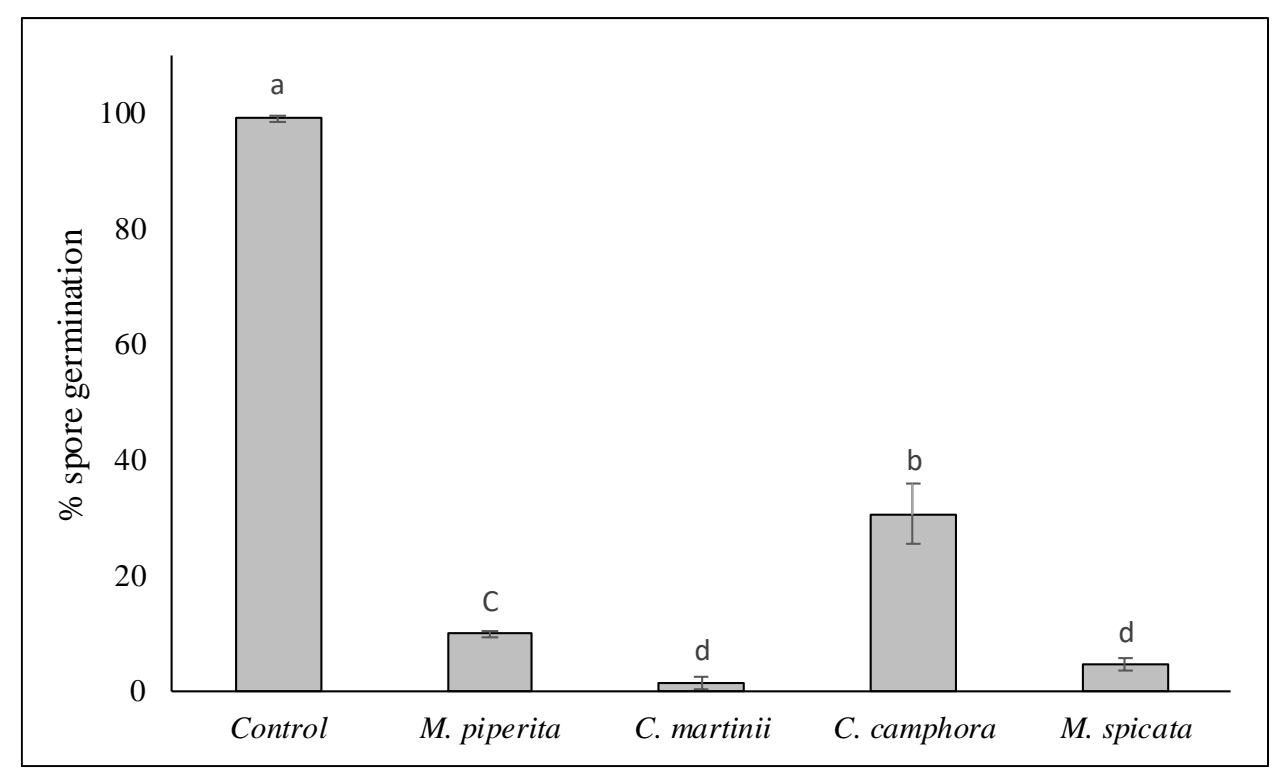

Figure 1. Inhibition of $R$. stolonifer spore germination by essential oils of Mentha piperita, Cymbopogon martinii, Cinnamomum camphora, and Mentha spicata at $0.1 \%$ concentration. Different letters represent a significant difference between the essential oils by the Tukey test $(\mathrm{p}<0.05)$.

\subsection{Micro-well dilution assay.}

Among the EOs tested, those of $C$. martinii and $M$. spicata showed the highest antifungal activity, with MIC values of $5 \mu \mathrm{g} / \mathrm{mL}$ and $10 \mu \mathrm{g} / \mathrm{mL}$ and both with MFC of 10 $\mu \mathrm{g} / \mathrm{mL}$, respectively. In comparison, EOs of $M$. piperita and C. camphora had the lowest antifungal activity with MIC and MFC values of $20 \mu \mathrm{g} / \mathrm{mL}$, against $R$. stolonifer (Table 1). 
Table 1. Minimum inhibitory concentration (MIC) and minimum fungicidal concentration (MFC) of essential oils against $R$. stolonifer by micro-well dilution method.

\begin{tabular}{c|c|c} 
Essential oils & MIC $(\boldsymbol{\mu g} / \mathbf{m L})$ & MCF $(\boldsymbol{\mu g} / \mathbf{m L})$ \\
\hline M. piperita & 20 & 20 \\
\hline C. martini & 5 & 10 \\
\hline C. camphora & 20 & 20 \\
\hline M. spicata & 10 & 10
\end{tabular}

The high antifungal activity of EOs of M. spicata and C. martinii appears to be related to their chemical composition. M. spicata EO is rich in carvone, which has high antifungal activity [22], while that of $C$. martinii EO may be related to the presence and interactions between its major ingredients, geraniol, geranyl acetate, linalool, and karyophylene [23].

Relatively lower antifungal activity of $M$. piperita EO compared to those of M. spicata and $C$. martini (Table 1) may be due to the presence of poorly-soluble menthol acetate [22] in it composition. This result corroborates the weak antifungal activity of $M$. piperita EO compared to that of $M$. spicata and $C$. martinii EOs, reported by others [22,24]. C. camphora EO's low efficacy here is probably due to the high concentration of linalool (98\%), which is reported to have poorer antifungal effects than compounds found in other EOs [25,26].

\subsection{In vivo tests: determination of the antifungal activity of essential oil vapors against $B$.} cinerea on strawberries.

Since EOs of M. spicata and C. martinii showed the best results in in vitro tests, their in vivo antifungal activity in the vapor phase was investigated. Figures 2 and 3 show the effectiveness of $M$. spicata and $C$. martinii EOs in controlling $R$. stolonifer in strawberries. $M$. spicata and $C$. martinii EOs were able to reduce the incidence and severity of rot caused by $R$. stolonifer in strawberries, stored at $25^{\circ} \mathrm{C}$ for 3 days. The inhibitory effect of the EOs was directly dependent on their dose (Figure 3). At the highest concentration tested (10\%), $M$. spicata and C. martinii EOs showed 100 and 78\% inhibition, respectively. These results are consistent with the report of Hosseini, Amini, Saba, Karimi, and Pertot [11], using EOs of Allium sativum (garlic) and Rosmarinus officinalis (rosemary) in the vapor phase to control Colletotrichum gloeosporioides in strawberries. In the present study, a similarly created controlled atmosphere to evaluate the EOs against $R$. stolonifer in strawberries resulted in inhibition comparable to that described by Hosseini, Amini, Saba, Karimi, and Pertot [11].

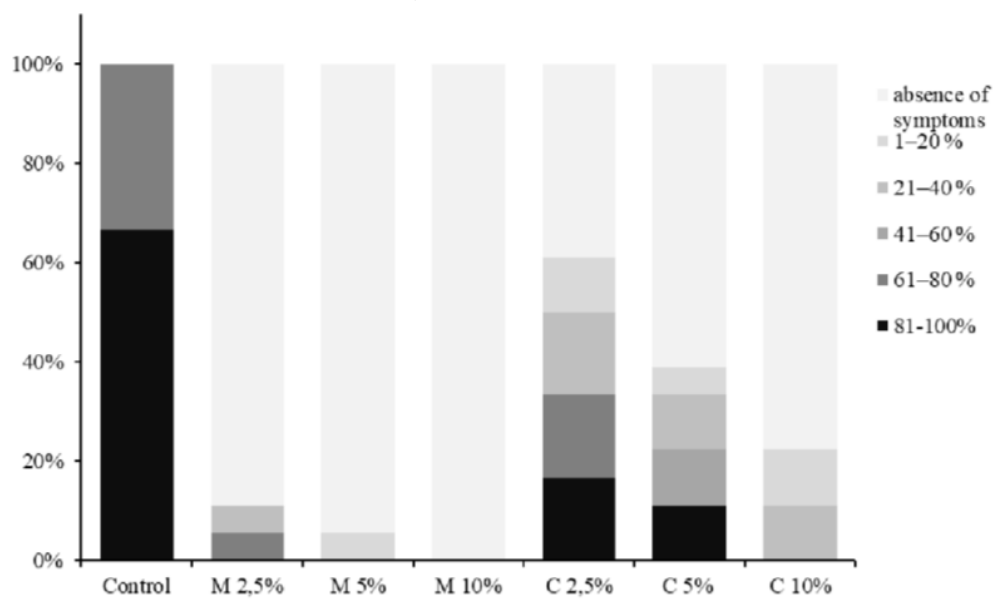

Figure 2. Severity of $B$. cinerea in post-harvest strawberries treated with $M$. spicata and $C$. martinii essential oils in vapor-phase and stored at $25 \pm 2{ }^{\circ} \mathrm{C} / 80 \pm 5 \% \mathrm{RH}$ for 7 days $(\mathrm{n}=18)$. Different letters represent a significant difference between the treatments using the Kruskal-Wallis ( $\mathrm{p}<0.05)$. Control: distilled water containing Tween 80; M2.5, M5, and M10: M. spicata essential oil at 2.5, 5, and 10\%, respectively; C2.5, C5, and C10: C. martinii essential oil at 2.5, 5, and 10\%, respectively. 


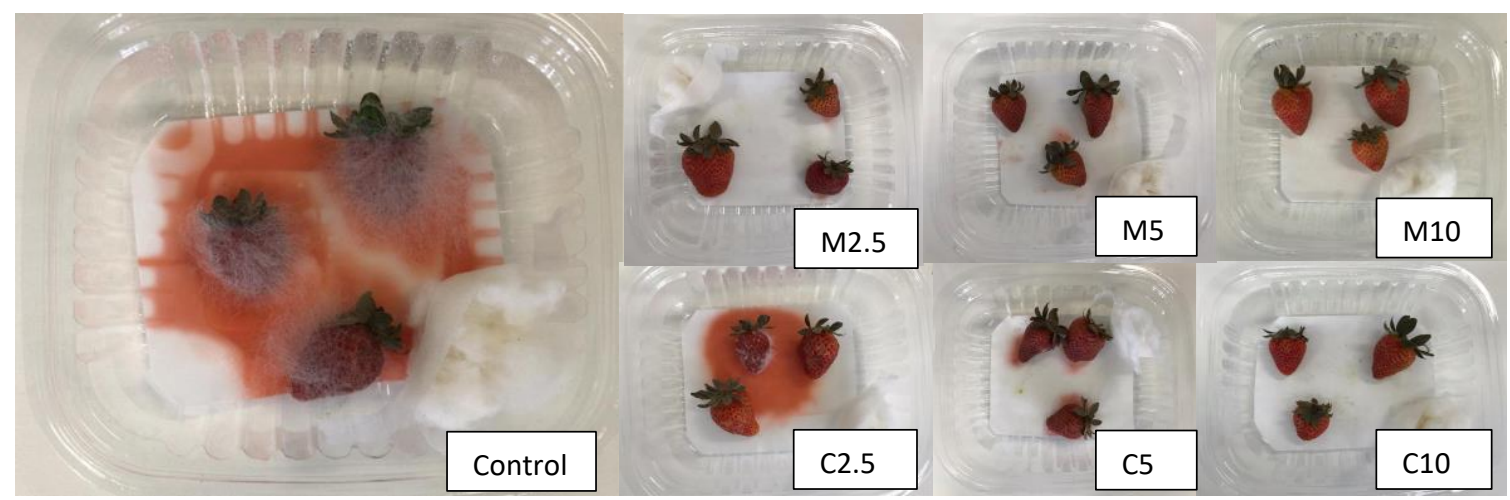

Figure 3. Strawberries inoculated with $R$. stolonifera and treated with $M$. spicata and $C$. martinii essential oils in vapor-phase before being stored at $25 \pm 2{ }^{\circ} \mathrm{C} / 80 \pm 5 \% \mathrm{RH}$, for 7 days. Control: distilled water containing Tween 80; M2.5, M5, and M10: M. spicata essential oil at 2.5, 5, and 10\%, respectively; C2.5, C5, and C10: $C$. martinii essential oil at $2.5,5$, and $10 \%$, respectively

\section{Conclusions}

Our results show that essential oils of $C$. martinii and $M$. spicata had the greatest antifungal activity according to spore germination and micro-well dilution assays. The application of essential oils in the vapor phase effectively reduced the severity and incidence of $R$. stolonifer infection in artificially inoculated strawberries. Therefore, $C$. martinii and $M$. spicata essential oils can be used as potential natural fungicides, which can be better alternatives to synthetic fungicides to control the soft rot in fresh strawberries.

\section{Funding}

This research was funded by FAPESP (process 2018/24612-9), CAPES (001), CNPq (process 407956/2016-6; scholarship 101117/2018-3), IF Goiano (Process 23218.002967.2020-38), Empresa Brasileira de Pesquisa Agropecuária (Embrapa), Rede Agronano, and MCTI-SisNano from Brazil. Authors Azeredo and Ferreira thank CNPq for their Research Productivity fellowships (302381/2016-3 and 310728/2019-3, respectively).

\section{Acknowledgments}

This research has no acknowledgment.

\section{Conflicts of Interest}

The authors declare no conflict of interest. The funders had no role in the study's design; in the collection, analyses, or interpretation of data; in the writing of the manuscript, or in the decision to publish the results.

\section{References}

1. Zeist, A.R.; de Resende, J.T.V. Strawberry breeding in Brazil: current momentum and perspectives. Horticultura Brasileira 2019, 37, 7-16, https://doi.org/10.1590/s0102-053620190101.

2. Guiné, R.d.P.F.; Correia, P.M.d.R.; Ferrão, A.C.; Gonçalves, F.; Lerat, C.; El-Idrissi, T.; Rodrigo, E. Evaluation of phenolic and antioxidant properties of strawberry as a function of extraction conditions. Brazilian Journal of Food Technology 2020, 23, https://doi.org/10.1590/1981-6723.14219.

3. Azam, M.; Ejaz, S.; Rehman, R.N.U.; Khan, M.; Qadri, R. Postharvest Quality Management of Strawberries. In Strawberry-Pre-and Post-Harvest Management Techniques for Higher Fruit Quality, IntechOpen: 2019. 
4. Li, C.; Wang, J.; Ji, N.; Lei, C.; Zhou, D.; Zheng, Y.; Wang, K. PpHOS1, a RING E3 ubiquitin ligase, interacts with PpWRKY22 in the BABA-induced priming defense of peach fruit against Rhizopus stolonifer. Postharvest Biol. Technol. 2020, 159, 111029, https://doi.org/10.1016/j.postharvbio.2019.111029.

5. Hyde, K.D.; Xu, J.; Rapior, S.; Jeewon, R.; Lumyong, S.; Niego, A.G.T.; Abeywickrama, P.D.; Aluthmuhandiram, J.V.S.; Brahamanage, R.S.; Brooks, S.; Chaiyasen, A.; Chethana, K.W.T.; Chomnunti, P.; Chepkirui, C.; Chuankid, B.; de Silva, N.I.; Doilom, M.; Faulds, C.; Gentekaki, E.; Gopalan, V.; Kakumyan, P.; Harishchandra, D.; Hemachandran, H.; Hongsanan, S.; Karunarathna, A.; Karunarathna, S.C.; Khan, S.; Kumla, J.; Jayawardena, R.S.; Liu, J.-K.; Liu, N.; Luangharn, T.; Macabeo, A.P.G.; Marasinghe, D.S.; Meeks, D.; Mortimer, P.E.; Mueller, P.; Nadir, S.; Nataraja, K.N.; Nontachaiyapoom, S.; O’Brien, M.; Penkhrue, W.; Phukhamsakda, C.; Ramanan, U.S.; Rathnayaka, A.R.; Sadaba, R.B.; Sandargo, B.; Samarakoon, B.C.; Tennakoon, D.S.; Siva, R.; Sriprom, W.; Suryanarayanan, T.S.; Sujarit, K.; Suwannarach, N.; Suwunwong, T.; Thongbai, B.; Thongklang, N.; Wei, D.; Wijesinghe, S.N.; Winiski, J.; Yan, J.; Yasanthika, E.; Stadler, M. The amazing potential of fungi: 50 ways we can exploit fungi industrially. Fungal Diversity 2019, 97, 1-136, https://doi.org/10.1007/s13225-019-00430-9.

6. Ons, L.; Bylemans, D.; Thevissen, K.; Cammue, B. Combining Biocontrol Agents with Chemical Fungicides for Integrated Plant Fungal Disease Control. Microorganisms 2020, 8, 1930, https://doi.org/10.3390/microorganisms8121930.

7. Raveau, R.; Fontaine, J.; Lounès-Hadj Sahraoui, A. Essential Oils as Potential Alternative Biocontrol Products against Plant Pathogens and Weeds: A Review. Foods 2020, 9, 365, https://doi.org/10.3390/foods9030365.

8. Nakatsu, T.; Lupo, A.T.; Chinn, J.W.; Kang, R.K.L. Biological activity of essential oils and their constituents. In Stud. Nat. Prod. Chem., Atta ur, R., Ed. Elsevier: 2000; Vol. 21, 571-631, https://doi.org/10.1016/S15725995(00)80014-9.

9. Wińska, K.; Mączka, W.; Łyczko, J.; Grabarczyk, M.; Czubaszek, A.; Szumny, A. Essential Oils as Antimicrobial Agents-Myth or Real Alternative? Molecules 2019, 24, 2130, https://doi.org/10.3390/molecules24112130.

10. Reyes-Jurado, F.; Navarro-Cruz, A.R.; Ochoa-Velasco, C.E.; Palou, E.; López-Malo, A.; Ávila-Sosa, R. Essential oils in vapor phase as alternative antimicrobials: A review. Crit. Rev. Food Sci. Nutr. 2020, 60, 1641-1650, https://doi.org/10.1080/10408398.2019.1586641.

11. Hosseini, S.; Amini, J.; Saba, M.K.; Karimi, K.; Pertot, I. Preharvest and Postharvest Application of Garlic and Rosemary Essential Oils for Controlling Anthracnose and Quality Assessment of Strawberry Fruit During Cold Storage. Front. Microbiol. 2020, 11, 1855, https://doi.org/10.3389/fmicb.2020.01855.

12. Amiri, A.; Mottaghipisheh, J.; Jamshidi-Kia, F.; Saeidi, K.; Vitalini, S.; Iriti, M. Antimicrobial Potencies of Major Functional Foods' Essential Oils in Liquid and Vapor Phases: A Short Review. Applied Sciences 2020, 10, 8103, https://doi.org/10.3390/app10228103.

13. El Ouadi, Y.; Manssouri, M.; Bouyanzer, A.; Majidi, L.; Bendaif, H.; Elmsellem, H.; Shariati, M.A.; Melhaoui, A.; Hammouti, B. Essential oil composition and antifungal activity of Melissa officinalis originating from north-Est Morocco, against post-harvest phytopathogenic fungi in apples. Microb. Pathog. 2017, 107, 321-326, https://doi.org/10.1016/j.micpath.2017.04.004.

14. Oliveira Filho, J.G.d.; da Cruz Silva, G.; de Aguiar, A.C.; Cipriano, L.; de Azeredo, H.M.C.; Bogusz Junior, S.; Ferreira, M.D. Chemical composition and antifungal activity of essential oils and their combinations against Botrytis cinerea in strawberries. Journal of Food Measurement and Characterization 2021, https://doi.org/10.1007/s11694-020-00765-X.

15. Pimentel, R.B.Q.; Souza, D.P.; Albuquerque, P.M.; Fernandes, A.V.; Santos, A.S.; Duvoisin, S.; Gonçalves, J.F.C. Variability and antifungal activity of volatile compounds from Aniba rosaeodora Ducke, harvested from Central Amazonia in two different seasons. Industrial Crops and Products 2018, 123, 1-9, https://doi.org/10.1016/j.indcrop.2018.06.055.

16. Broekaert, W.F.; Terras, F.R.G.; Cammue, B.P.A.; Vanderleyden, J. An automated quantitative assay for fungal growth inhibition. FEMS Microbiol. Lett. 1990, 69, 55-59, https://doi.org/10.1111/j.15746968.1990.tb04174.x.

17. Ali, A.; Wee Pheng, T.; Mustafa, M.A. Application of lemongrass oil in vapour phase for the effective control of anthracnose of 'Sekaki' papaya. J. Appl. Microbiol. 2015, 118, 1456-1464, https://doi.org/10.1111/jam.12782.

18. Cia, P.; Benato, E.A.; Pascholati, S.F.; Garcia, E.O. Chitosan on the post-harvest control of soft rot in'rama forte'persimmon. Bragantia 2010, 69, 745-752, https://doi.org/10.1590/S0006-87052010000300028. 
19. Tomazoni, E.Z.; Pauletti, G.F.; da Silva Ribeiro, R.T.; Moura, S.; Schwambach, J. In vitro and in vivo activity of essential oils extracted from Eucalyptus staigeriana, Eucalyptus globulus and Cinnamomum camphora against Alternaria solani Sorauer causing early blight in tomato. Scientia Horticulturae 2017, 223, 72-77, https://doi.org/10.1016/j.scienta.2017.04.033.

20. Fialho, R.d.O.; Papa, M.d.F.S.; Pereira, D.A.d.S. Fungitoxic effect of essential oils on Phakopsora euvitis, causal agent of grape rust. Arq. Inst. Biol. (Sao Paulo) 2015, 82, https://doi.org/10.1590/18081657000702013.

21. Lorenzetti, E.R.; Monteiro, F.P.; Souza, P.E.; Souza, R.J.; Scalice, H.K.; Diogo Júnior, R.; Pires, M.S.O. Essential oils bioactivity in strawberry grey mould control. Revista Brasileira de Plantas Medicinais 2011, 13, 619-627, https://doi.org/10.1590/S1516-05722011000500019.

22. Soković, M.D.; Vukojević, J.; Marin, P.D.; Brkić, D.D.; Vajs, V.; Van Griensven, L.J.L.D. Chemical composition of essential oilsof thymus and mentha speciesand their antifungal activities. Molecules 2009, 14, 238-249, https://doi.org/10.3390/molecules14010238.

23. da Rocha Neto, A.C.; Navarro, B.B.; Canton, L.; Maraschin, M.; Di Piero, R.M. Antifungal activity of palmarosa (Cymbopogon martinii), tea tree (Melaleuca alternifolia) and star anise (Illicium verum) essential oils against Penicillium expansum and their mechanisms of action. LWT 2019, 105, 385-392, https://doi.org/10.1016/j.lwt.2019.02.060.

24. Pattnaik, S.; Subramanyam, V.R.; Kole, C. Antibacterial and antifungal activity of ten essential oils in vitro. Microbios 1996, 86, 237.

25. Abd El-Baky, R.M.; Hashem, Z.S. Eugenol and linalool: comparison of their antibacterial and antifungal activities. Afr. J. Microbiol. Res. 2016, 10, 1860-1872, https://doi.org/10.5897/AJMR2016.8283.

26. Simionatto, E.; Porto, C.; Stüker, C.Z.; Dalcol, I.I.; Silva, U.F.d. Chemical composition and antimicrobial activity of the essential oil from Aeolanthus suaveolens Mart. ex Spreng. Quim. Nova 2007, 30, 1923-1925, https://doi.org/10.1590/S0100-40422007000800024. 